\title{
Relationship of Initial Glascow Coma Scale Score and Treatment Duration with Independency Level of Patients with Head Injury in Emergency Room Dr. R. Koesma Tuban Hospital
}

\author{
Moh. Ubaidillah Faqih \\ STIKES Nadhlatul Ulama \\ Tuban, Indonesia \\ moh.ubaidillah.faqih@gmail.com
}

\author{
Hyan Oktodia Basuki \\ Faculty of Nursing Universitas Airlangga \\ Surabaya, Indonesia \\ hyancassava@gmail.com
}

\begin{abstract}
Head injury is the main cause of disability and mortality. Several factors that can lead to high disability are the initial GCS score and the treatment duration. The purpose of this study was to determine the relationship of initial GCS score and treatment duration to the independence level of patients with head injury. This study was an observational analytic study with retrospective review of 107 samples from medical record dr. $R$. Koesma Tuban Hospital in the period from January to April 2016. The sampling technique used was cluster random sampling with the inclusion and exclusion criteria. Measurement was conducted using Functional Independence Measure (FIM). The result analyzed using contingency coefficient test. The test results contingency showed that both factors (GCS $(p=0.000)$ and duration of treatment $(p=0.000)$ ) was significant to the independence level of head injury patients. The conclusion of this study was the initial GCS score, and duration of treatment were factor that associated with head injury patients independence level. Therefore, nurses need to improve the management of head injury patients in the emergency phase without neglecting the initial GCS score and duration of treatment.
\end{abstract}

Keywords-Independence, Head Injury, GCS, Duration of Treatment

\section{INTRODUCTION}

Head injuries caused by traffic accidents are the main cause of disability and mortality in developing countries. This situation generally occurs in the motor driver without a safety standard such as using helmet or wearing a helmet improperly[1]. Thirty till sixty percents of head injury patients with uncontrolled Intra Cranial Pressure (ICP) was died, and this results different from other studies which found that better outcomes result with moderate disability[2].

Tuban district passed the main line linking the northern coast of Jakarta Semarang Surabaya. The high volume of vehicles could result in congestion and can lead to other problems such as the incidence of traffic accidents. The northern Gaza region that includes roads Tuban had a problem that is likely to increase the incidence of accidents.

Based on data during 2009-2013, the incidence of traffic accidents on the northern coastline that passed through the region Tuban tend to increase. The number of traffic accidents during the years 2009-2013 as many as 1,107 events. As result of that accident victims died 208 people, 249 seriously injured and 1,147 persons slightly injured victim. The year 2012 had the highest number of traffic accidents as many as 348 or $31.4 \%$ incidence with details of deaths 45 people, 65 people injured seriously and victims who suffered minor injuries as many as 411 people. Broadly speaking, the number of traffic accidents during the years 2009-2013 the average increased $17.03 \%$ per annum[3].

Determine the patients prognosis with severe head injuries often difficult, whereas an accurate prognosis is very important to give an informed consent[4]. This is due to the limitations of the initial clinical assessment, duration of treatment in patients with head injury, as well as the number of factors and variables that influence[5].

Several factors such as age, mechanism of injury, the initial score on the Glasgow Coma Scale (GCS), hypotension, pupil diameter and the light reactions, computed tomography (CT) scan, use of alcohol and drugs[6]. Appropriate outcome assessment obtained at 3,6 and 12 months after brain injury. The patient's condition improved clinically significant, especially six months after brain injury [7].

Functional independence measure (FIM) is a measurement tool used to assess the patient's dependence[8]. This instrument can used in common by all parties, namely doctors, nurses, physiotherapists, patient or family. Judgment includes physical abilities or motor including vegetative function, and cognitive abilities such as communication and interaction with people around[9].

The purpose of this study was to determine the relationship initial GCS and Lama hospitalized with head injuries independence in patients who had been treated in the ER dr. R. Koesma Tuban. 
TABLE I. FREQUENCY DISTRIBUTION CHARACTERISTICS OF RESPONDENTS

\begin{tabular}{|c|c|c|}
\hline Characteristics & $\mathbf{N}$ & $\%$ \\
\hline \multicolumn{3}{|l|}{ Gender } \\
\hline Male & 59 & 55.1 \\
\hline Female & 48 & 44.9 \\
\hline \multicolumn{3}{|l|}{ Age } \\
\hline 1-4 years & 1 & 0.9 \\
\hline 5-14 years & 17 & 15.9 \\
\hline 15-24 years & 26 & 24.3 \\
\hline 25-44 years & 29 & 27.1 \\
\hline 45-59 years & 21 & 19.6 \\
\hline$>59$ & 13 & 12.1 \\
\hline \multicolumn{3}{|l|}{ Head injury } \\
\hline Minor & 78 & 72.9 \\
\hline Severe & 29 & 27.1 \\
\hline Total & 107 & 100 \\
\hline \multicolumn{3}{|c|}{ Source: Primary Data (2016) } \\
\hline
\end{tabular}

TABLE II. RESULTS OF ANALYSIS OF CONTINGENCY COEFFICIENT BIVARIAT

\begin{tabular}{cccc}
\hline Variable & n & r & p \\
\hline GCS & $\mathbf{1 0 7}$ & $\mathbf{0 , 4 2 3}$ & $\mathbf{0 , 0 0 0}$ \\
\hline Duration of treatment & $\mathbf{1 0 7}$ & $\mathbf{0 , 3 5 1}$ & $\mathbf{0 , 0 0 0}$ \\
\hline
\end{tabular}

Source: Primary Data (2016)

\section{METHODS}

This study was an observational analytic study using a retrospective review in 107 sample design from their medical record in dr. R. Koesma Tuban from the period January to April 2016 and then made a home visit to assess the independence level using Functional Independence Measure (FIM). The sampling technique used was cluster random sampling technique with the inclusion criteria: 1) The patient is still alive, 2) Patients with impaired immobilization, 3) Patients with $\leq 6$ months after injury, 3) Patients who live in Tuban, 4) Patients willing to become respondents

The exclusion criteria was medical records of patients with head injury referral> 48 hours of the occurrence of injury and patients with other disorders. The measurement of this study used basic collection sheets, checklists and FIM. The result was tested by bivariate analysis using contingency coefficient test.

\section{RESULT}

Based on data from the ER dr. R. Koesma Tuban incidence of trauma and emergency medical service due to an accident in the North Coast Region (coast) increased by 5\% from 2014 and in January to April 2016, due to a head injury patient visits in general amounted to $175(100 \%)$ of the cases; Most cases are due to traffic accidents amounted to 86 (55.8\%) cases and respondents who live in Tuban amounted to 146 $(83.4 \%)$, here in after the population in this study.

The study was conducted from May to July 2016 in dr. R. Koesma Tuban to collect preliminary data on age, mechanism of injury, hypotension, GCS, pupil state circumstances, the results of CT scan, alcohol consumption, long day care at the Hospital of the Medical Record and to establish population head injuries had been treated in the ER as much 146 respondents. Presentation of the results were analyzed by univariate and bivariate analysis.

Based on table 1, it can be seen that the number of respondents who suffered a head injury and who had been treated in the ER dr. R. Koesma Tuban, most were male with the number of $59(55.1 \%)$ of respondents, aged 15-24 years with a number of $29(27.1 \%)$ of respondents and minor head injuries to $78(72.9 \%)$ of respondents.

Based on Table 2, it can be seen that the variable GCS (p $<0.001)$, and Length of hospitalization $(\mathrm{p}<0.001)$.

\section{DISCUSSION}

\section{A. Relationship with Independence GCS}

Based on Table 2, it can be seen that the variable GCS (p $<0.001)$ is related to the independence of head injury patients with moderate correlation $(r=0.432)$, and the direction of the positive correlation which means the weight of the independence of the higher GCS (dependent). This is because there are differences in amount of light higher GCS with the independence of the independent category that is more dominant, which means that a variety of data variation.

According[10], GCS score before resuscitation associated with mortality and functional outcomes in patients with head injury, but the limitations inherent characteristics must be adapted to the conditions in each of the clinical prognosis of patients with a predicted outcome in various population groups. GCS score as a specific indicator on head injury is often obscured by a variety of things such as the gap between supply and demand of oxygen caused by circumstances such as anemia, hypotension, or hypoxia. Also due to the effects of central nervous system depression due to drugs[10].

Glasgow coma scale (GCS) is a measure used to assess clinical severity of injury in severe head injury. Glasgow coma scale should have been examined in patients in the early injury, especially before getting paralytic drugs and before intubation; This score is called initial GCS score. The degree of awareness seems to have a strong influence on the chance of life and healing. Glasgow coma scale is also a strong predictive factor in determining prognosis, a GCS score lower on early injury associated with poor prognosis[11].

According [12], reported that $82 \%$ of patients with a GCS score of 11 or more, within 24 hours after the injury have a good outcome or moderately disabled and only $12 \%$ died or received severe disability. Outcome will progressively decrease when initial GCS score decreased. Among patients with initial GCS score of 3 or 4 in the first 24 hours after injury only $7 \%$ who got good outcome or moderate disability. Among patients with a GCS score of 3 at the time was treated, $87 \%$ will die. Loss of consciousness long, in many respects is not predictive of a poor outcome. 


\section{B. Relationship Duration of treatment with Independence}

Based on this research, it is known that the variable length of stay ( $p<0.001$ ) is related to the independence of head injury patients, with a weak correlation $(r=0.351)$, and the direction of the positive correlation which means that the longer the patient at the Hospital of the independence of the higher (dependent). This is because there are differences in amount of length of <3 days were higher with the independence of the independent category that is more dominant, which means that a variety of data variation.

Length of Stay is longer care given to the patient by a health service. Old hospital patient care must be influenced by many factors, one of which is the initial management of patients is good and right will determine the outcome. Research on the outcome of a head injury showed that the GCS will increase morbidity and mortality will affect the Length of Stay of patients in hospitals[12].

Each year about 200,000 head injuries occurrence requiring hospitalization where 1.74 million people 280 patients with head injury being suffered temporary disability of at least 1 day. Length of stay of head injury patient care in the ER varies depending on the severity of injury to the patient [13]. Mild head injury patients for 3 days with a minimum treatment duration 1 day and a maximum of 7 days and the most influential factor in predicting treatment duration is a head injury patients GCS[14].

\section{CONCLUSIONS}

From the results obtained, it can be concluded that the two variables (GCS and long day care) relates to the independence of head injury patients in head injury patients who had been treated in the ER dr. R. Koesma Tuban. Further study should examine the time needed to do initial assessment using Glasgow coma scale to get maximum outcome of patients condition.

\section{References}

[1] Wijayanti, "Asuhan keperawatan pada Tn. S dengan gangguan sistem persyarafan: cedera kepala post kraniotomi hari ke-2 di Ruang Sofa Rumah Sakit PKU Muhammadiyah,” Surakarta, 2012.

[2] R. Moulton and L. Pitts, "Head Injury and Intracranial Hypertension," in Principles of Critical Care, 3rd ed., USA: McGraw Hill., 2005.

[3] S. Rosyida, N. Daryono, and K. Prasetyo, "Kajian Kecelakaan Lalu Lintas Di Jalan Arteri Pada Jalur Pantura Wilayah Tuban," Swara Bhumi Vol 1, No 1, 2015.

[4] P. Blumbergs, "Neuropathology of traumatic brain injury," in Youmans Neurological Surgery, 6th ed., H. Winn, Ed. Philadelphia: Elsevier Saunders, 2011.

[5] J. Hadi, "Pengaruh koagulopati terhadap glasgow outcome scale penderita cedera kepala berat yang tidak mempunyai indikasi operasi," Universitas Andalas, 2014.

[6] J. Jiang, "Head trauma in China," Inj. Int. J.Care Inj., vol. 44, pp. 1453 1457,2012

[7] C. D. Arnold, "Faktor - Faktor Yang Berhubungan Dengan Outcome Pasien Pasca Operasi Hematoma Epidural (EDH)," Universitas Andalas, 2013.

[8] Canadian Partnership for Stroke Recovery, "Functional Independence Measure (FIM) Evaluation Summary," 2016. [Online]. Available: http://www.strokengine.ca.

[9] J. Van Middendorp, A. Hosman, A. Donders, M. Pouw, J. Ditunno, and A. Curt, "A clinical prediction rule for ambulation outcomes after traumatic spinal cord injury: a longitudinal cohort study," Lancet, vol. 377, no. 9770, p. 1004-1010., 2011.

[10] P. Udekwu, S. Kromhout-Schiro, S. Vaslef, C. Baker, and D. Oller, "Glasgow coma scale score, mortality, and functional outcome in headinjured patients," J Trauma, vol. 56, pp. 1084-1089, 2004.

[11] M. Arifin and J. Henky, "Analisis nilai functional independence measure penderita cedera servikal dengan perawatan konservatif," Makara Kesehat., vol. 16, no. 1, pp. 17-22, 2012.

[12] A. G. Sastrodiningrat, "Memahami Faktor-Faktor yang Mempengaruhi Prognosa Cedera Kepala Berat," Suplemen Majalah Kedokteran Nusantara, Sep-2006.

[13] Bethel, "Emergency Care of Children and Adults With Head Injury," Nurs. Stand., vol. 43, pp. 49-56, 2012.

[14] N. P. Sipayung and H. Syapitri, "GCS sebagai prediktor lenght of stay pasien CKR di RSU Pringadi Medan,” INJEC, vol. 2, no. 2, 2015. 